\title{
STUDI LALAT PENGOROK DAUN LIRIOMYZA SPP. PADA PERTANAMAN BAWANG DAUN, DAN PARASITOID OPIUS CHROMATOMYIAE BELOKOBYLSKIJ \& WHARTON (HYMENOPTERA: BRACONIDAE)
}

\author{
Rusli Rustam¹, Aunu Rauf ${ }^{2}$, Nina Maryana ${ }^{2}$, Pudjianto ${ }^{2}$, dan Dadang ${ }^{2}$
}

\begin{abstract}
Studies on Leafminer Liriomyza spp. in Green Onion Fields, and Parasitoid Opius chromatomyiae Belokobylskij \& Wharton (Hymenoptera: Braconidae). Field studies were conducted to determine population abundance of leafminers and their parasitoids in green onion fields in Puncak, West Java. In addition to that, laboratory studies were carried out to determine demographic parameter of Opius chromatomyiae as well as response of parasitoid to increasing host density. Results revealed that green onions were infested by two species of leafminers, Liriomyza huidobrensis and Liriomyza chinensis. Leafminer flies emerged from Erwor leaves (54.5) were significantly higher than those of RP leaves (18.65) $(\mathrm{P}=$ 0.0005). However, number of leafminer flies caught on sticky traps was not statistically different $(P=0.297)$. Two species of parasitoid, Hemiptarsenus varicornis and $O$. chromatomyiae, were associated with leafminers in green onion fields. Higher number of parasitoids emerged from Erwor leaves (13.68) as compared to RP (6.90) $(\mathrm{P}=0.0007)$. However, level of parasitization were $24.36 \%$ on Erwor and $28.45 \%$ on $\mathrm{RP}$, and was not significantly different $(\mathrm{P}=0.387)$. Laboratory studies indicated that net reproduction (Ro) of $O$. chromatomyiae was 28.55 , generation time (T) 15.96 days, intrinsic growth rate 0.21 , and total of reproductive value 223.64 . The stable age distribution of parasitoid were $37.93 \%$ eggs, $24.92 \%$ larvae, $20.36 \%$ pupae and $16.78 \%$ adults. The parasitoid showed functional response type II to increasing host density, with a $=0.08$ and $\mathrm{Th}=2.58$.
\end{abstract}

Keyword : Liriomyza huidobrensis, Liriomyza chinensis, Opius chromatomyiae, demographic parameters, functional response

\section{PENDAHULUAN}

Lalat pengorok daun Liriomyza huidobrensis (Blanchard) (Diptera: Agromyzidae) pertama kali dilaporkan keberadaannya di Indonesia pada tahun 1994 (Rauf, 1995), dan saat ini telah menjadi hama utama pada pertanaman sayuran dataran tinggi. Lalat ini bersifat polifag yang dapat menyerang 45 spesies tanaman dari Famili Cruciferae, Liliaceae, Cucurbitaceae, Umbelliferae, Compositae, Amaranthaceae, Chenopodiaceae, Solanaceae, Euphorbiaceae, Convolvulaceae, Basellaceae dan Labitaceae (Rauf et al., 2000). Sementara itu, pada tahun 2000 pertanaman bawang di Brebes untuk pertama kalinya diserang oleh Liriomyza chinensis Kato (Rauf, 2003). Serangan Liriomyza spp. dapat mengakibatkan kerusakan jaringan-jaringan mesofil daun sehingga fotosintesis berkurang (Minkenberg \& van Lanteran, 1986).

Survei yang dilakukan pada pertanaman sayuran dataran tinggi Cianjur-Bogor mengungkapkan bahwa bawang daun merupakan tanaman sayuran yang mempunyai nilai ekonomi tinggi yang banyak ditanam oleh petani. Tingkat serangan lalat pengorok daun pada bawang daun dapat mencapai 90\% (Rustam et al., 2008).

Sejauh ini upaya pengendalian hama lalat pengorok daun masih bertumpu pada penggunaan insektisida sintetik, bahkan aplikasinya dapat mencapai 2-3 kali per minggu (Rauf, 1999). Padahal penggunaan insektisida yang berlebihan dapat menimbulkan dampak buruk seperti resistensi dan resurgensi hama, terbunuhnya musuh alami, dan pencemaran lingkungan secara umum (CEQ, 1972). Pemanfaatan musuh alami seperti parasitoid, saat ini tengah dikembangkan untuk menjembatani kepentingan pengendalian dan kesehatan lingkungan. Hingga kini di Indonesia dilaporkan terdapat 18 spesies parasitoid yang berasosiasi dengan larva Liriomyza spp. (Supartha, 1998; Rauf et al., 2000; Susilawati, 2002; Purnomo, 2003). Beberapa jenis parasitoid dominan adalah $H$. varicornis dan O. chromatomyiae (Supartha, 1998; Subaidi, 2002).

$O$. chromatomyiae adalah endoparasitoid larvapupa (Rustam, 2002) yang berpotensi dalam

\footnotetext{
${ }^{1}$ Jurusan Agronomi, Fakultas Pertanian, Universitas Riau, Kampus Bina Widya KM 12,5 Simpang Baru, Pekanbaru 28293

${ }^{2}$ Departemen Proteksi Tanaman, Fakultas Pertanian, IPB, Jl. Kamper Kampus Darmaga Bogor 16680
} 
pengendalian hayati lalat pengorok. Namun demikian, berbagai aspek dasar dalam upaya pengendalian masih belum banyak diteliti, seperti parameter demografi yang meliputi laju reproduksi, laju pertambahan instristik, dan masa generasi, serta kajian tanggap parasitoid terhadap kelimpahan inang (tanggap fungsional).

Penelitian ini bertujuan untuk (1) mempelajari perkembangan populasi Liriomyza spp. dan parasitoidnya, khususnya $O$. chromatomyiae pada bawang daun, (2) mempelajari potensi keefektifan parasitoid $O$. chromatomyiae berdasarkan parameter demografi yang meliputi laju pertambahan intristik (r), reproduksi bersih (Ro), masa generasi $(\mathrm{T})$, nilai reproduksi, dan persebaran umur stabil; dan (3) mengetahui potensi keefektifan parasitoid $O$. chromatomyiae berdasarkan tanggapnya terhadap peningkatan kelimpahan inang, serta menetapkan laju pelacakan inang (a) dan masa penanganan inang (Th).

\section{METODE PENELITIAN}

Penelitian dilaksanakan pada pertanaman sayuran di Kabupaten Cianjur dan Laboratorium Ekologi Serangga, Departemen Proteksi Tanaman, Fakultas Pertanian, Institut Pertanian Bogor. Penelitian berlangsung dari bulan Juni 2006 hingga Agustus 2007.

\section{Studi Kelimpahan Populasi Lalat Pengorok Daun}

Percobaan dilakukan pada pertanaman bawang daun yang ditanam pada lahan seluas $500 \mathrm{~m}^{2}$. Lahan percobaan dibagi menjadi delapan subpetak yang masing-masing berukuran $50 \mathrm{~m}^{2}$. Bawang daun ditanam dalam bedengan berukuran $5 \mathrm{~m} \mathrm{x} 1 \mathrm{~m}$. Jarak antar subpetak $75 \mathrm{~cm}$ dan jarak bedengan dalam subpetak 30 $\mathrm{cm}$.

Percobaan disusun dalam bentuk Rancangan Acak Kelompok dengan dua perlakuan, yakni bawang daun varietas RP dan Erwor dengan empat ulangan. Peubah yang diamati mencakup populasi imago lalat Liriomyza spp. yang terperangkap, jumlah Liriomyza dan parasitoid yang muncul, tingkat parasitisasi parasitoid, dan tingkat kerusakan tanaman.

Analisis ragam pengukuran berulang dilakukan untuk menentukan pengaruh perlakuan (varietas bawang daun) dan waktu selama kurun waktu pengamatan terhadap rataan kelimpahan lalat, kerusakan tanaman, banyaknya parasitoid yang muncul dan tingkat parasitisasi. Kemudian dilakukan uji lanjut dengan BNT $5 \%$ dengan bantuan progran SAS 9.0.

\section{Studi Parasitoid}

Pemeliharaan inang. Larva L. huidobrensis dipelihara pada tanaman kacang jogo (Vigna sinensis (L.) Hassk). yang berumur 14 hari. Tanaman kacang jogo dimasukkan ke dalam kurungan biakan $L$. huidobrensis dan setiap hari dilakukan pergantian tanaman inang. Tanaman inang yang telah diinfestasi telur lalat pengorok daun dipelihara sampai larva instar -3 , yang digunakan untuk perbanyakan dan sebagai inang pembiakan parasitoid.

Parameter demografi. Sintasan pradewasa diteliti dengan memaparkan 100 imago O. chromatomyiae pada dua puluh tanaman (10 pot), yang masing-masing terinfestasi sekitar 20-30 larva inang instar-3 selama dua jam. Kemudian tanaman dipindahkan dan dipelihara ke dalam kurungan lain. Setiap hari perkembangan dan mortalitas pradewasa $O$. chromatomyiae diamati dengan membedah 50 inang (larva atau pupa).

Sintasan imago dan banyaknya keturunan diamati dengan memaparkan sepasang imago $O$. chromatomyiae yang baru muncul pada daun kacang merah dengan sekitar 20-30 larva inang dalam kurungan stoples (diameter $12,5 \mathrm{~cm}$, tinggi $20 \mathrm{~cm}$ ). Setiap 24 jam dilakukan penggantian larva inang sampai imago parasitoid mati. Jantan yang mati segera diganti dengan yang baru. Percobaan dilakukan pada 22 imago betina. Telur yang diletakkan setiap hari dipelihara dengan memelihara larva yang terparasit sampai menjadi imago.

Parameter demografi $O$. chromatomyiae diduga dengan menggabungkan data perkembangan dan sintasan pradewasa, data masa hidup imago dan reproduksi, serta data nisbah kelamin seperti yang dilakukan oleh Lysyk (2000). Parameter demografi yang dihitung meliputi (Birch 1948; Carey 1993):

Laju reproduksi bersih $(\mathrm{Ro})=\sum \mathrm{L}_{\mathrm{x}} \mathrm{m}_{\mathrm{x}}$

Masa generasi $(T)=\sum x \cdot L_{x} m_{x} / R o$

Laju pertambahan intrinsik $(r)=\sum e^{r x} \cdot L_{x} m_{x}=1$

Laju pertambahan terbatas $(\lambda)=\mathrm{e}^{\mathrm{r}}$

Nilai reproduktif $(\mathrm{Vx} / \mathrm{Vo})=\left(\mathrm{e}^{-\mathrm{rx}} / \mathrm{Lx}\right) \cdot\left(\sum \mathrm{e}^{-\mathrm{ry}}\right.$ ly $\left.\cdot \mathrm{my}\right)$

Distribusi sebaran umur (px) : $100 \beta$ Lx $\mathrm{e}^{-\mathrm{r}(\mathrm{x}+1)}$

dengan $\mathrm{Lx}=$ Proporsi individu yang hidup pada umur $\mathrm{x}$; $\mathrm{mx}=$ Jumlah keturunan betina pada umur $\mathrm{x}$ (angka kelahiran); $\mathrm{x}=$ Kelas umur; dan $\mathrm{b}=$ Laju kelahiran terbatas 
Tanggap Fungsional. Ke dalam kurungan plastik silinder dengan diameter $12,5 \mathrm{~cm}$ dan tinggi $20 \mathrm{~cm}$ dimasukkan dua helai daun kacang jogo yang terinfestasi oleh larva pengorok instar-3 dengan berbagai kerapatan: $2,4,8,10,12,16,20$, dan 24 ekor. Sepasang parasitoid yang berumur 3 hari dipaparkan pada setiap kerapatan tersebut selama 24 jam. Selama percobaan, imago parasitoid diberi pakan berupa larutan madu $10 \%$.

Tanggap fungsional parasitoid dianalisis dengan regresi logistik antara proporsi inang yang terparasit $(\mathrm{Ne} /$ No) dan kerapatan inang yang tersedia (No) (Juliano, 1993) untuk melihat tipe tanggap fungsional. Selanjutnya ditentukan laju pencarian inang dan lama waktu penanganan dengan menggunakan model tipe- 2 menurut Holling (1959) sebagai berikut:

$$
\begin{aligned}
& \mathrm{Ne}=\mathrm{aTNo} /(1+\mathrm{aThNo}) \\
& \mathrm{Ne}=\text { banyaknya larva inang yang diparasit } \\
& \mathrm{No}=\text { banyaknya larva inang yang disediakan } \\
& \mathrm{a} \quad \text { laju pencarian inang } \\
& \mathrm{T} \quad=\text { lama waktu inang terpapar pada parasitoid } \\
& \mathrm{Th}=\text { lama waktu penanganan }
\end{aligned}
$$

Parameter-parameter tersebut (a dan Th) diduga secara iterasi dengan metode Newton (Juliano, 1993), dengan menggunakan prosedur PROC NLIN dari SAS 9.0.

\section{HASIL DAN PEMBAHASAN}

\section{Studi Lalat Pengorok Daun}

Kelimpahan Populasi. Perbedaan varietas tanaman bawang daun tidak berpengaruh nyata terhadap banyaknya lalat pengorok daun yang tertangkap perangkap kuning $(\mathrm{F}=5,13 ; \mathrm{db}=1,3 ; \mathrm{P}=0,297)$. Rataan banyaknya imago Liriomyza yang tertangkap perangkap kuning sebanyak 57,95 $\pm 36,33$ ekor pada varietas RP dan 68,13 $\pm 47,59$ ekor pada varietas Erwor. Tidak adanya perbedaan ini mungkin karena lalat yang tertangkap perangkap kuning dapat berasal dari petak di sekelilingnya, bukan dari petak perlakuan saja.

Hasil pengamatan terhadap banyaknya imago yang muncul dari daun contoh menunjukkan kecenderungan yang berbeda. Banyaknya imago lalat pengorok daun yang muncul dari bawang daun varietas Erwor lebih tinggi (54,5 $\pm 56,75$ ekor) dibandingkan yang muncul dari varietas $\mathrm{RP}(18,65 \pm 19,31$ ekor $)(\mathrm{F}=14,38$; $\mathrm{db}=1,3 ; \mathrm{P}=<0,001)$. Gambar 1 menyajikan banyaknya lalat pengorok daun yang muncul dari daun contoh menurut waktu. Pada pengamatan 1 MST, jumlah imago yang muncul dari daun contoh varietas RP sebanyak 12,25 individu, sedangkan pada daun bawang varietas Erwor jumlah imago yang muncul hampir 5 kali lipat dari varietas RP dengan jumlah 52,25 individu.

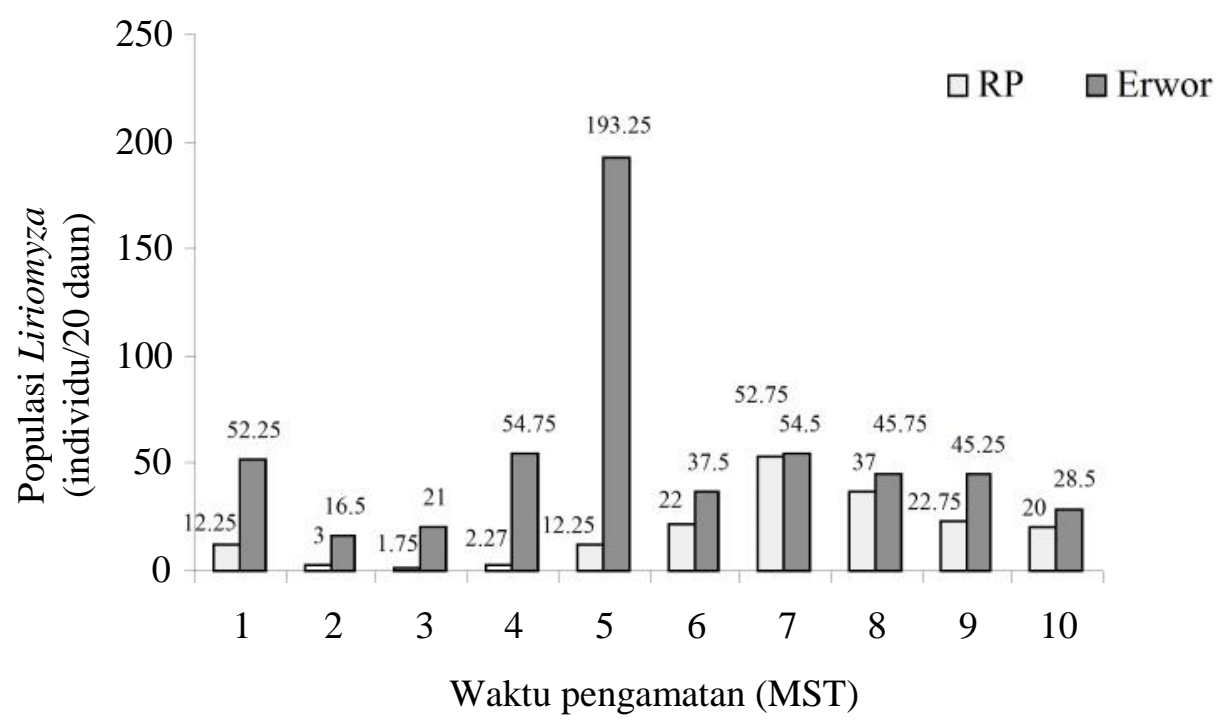

Gambar 1. Rataan banyaknya Liriomyza yang muncul dari daun contoh 

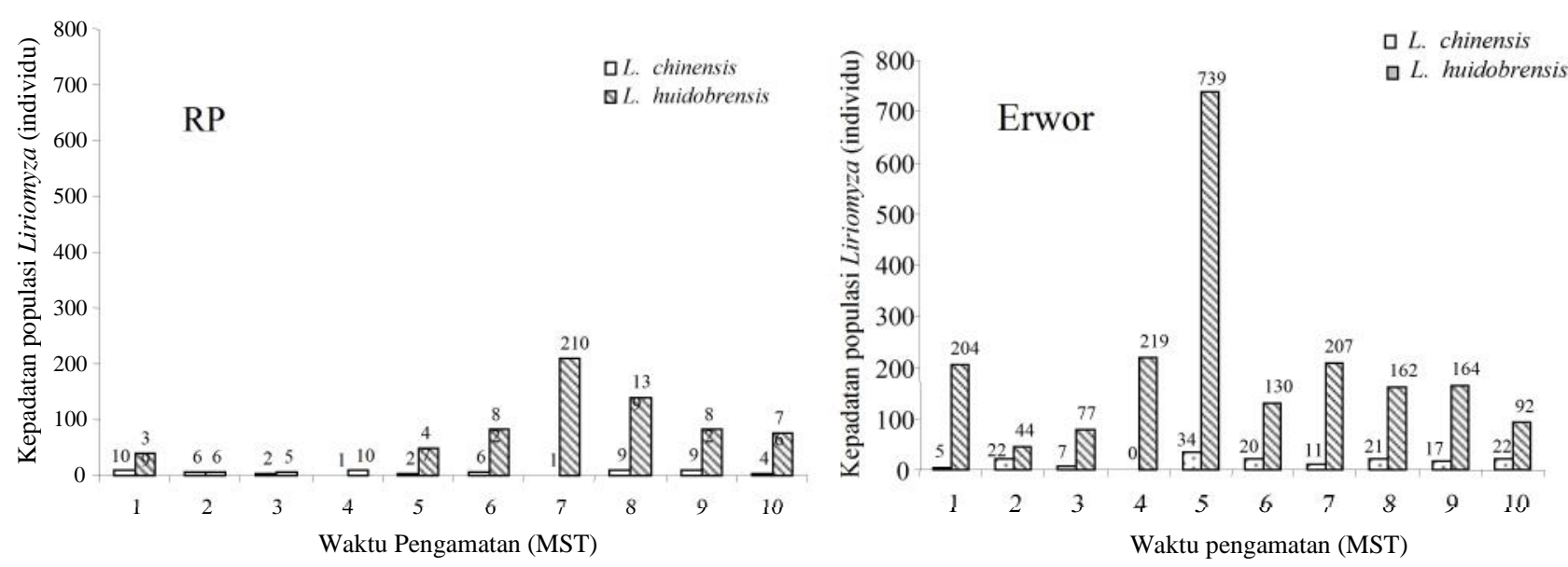

Gambar 2. Kelimpahan populasi Liriomyza huidobrensis dan Liriomyza chinensis pada dua varietas bawang daun

Perbedaan ini terlihat juga pada pengamatan 2, 3, 4, dan 5 MST dengan puncak populasi terjadi pada 5 MST, kemudian terjadi penurunan populasi pada mingguminggu berikutnya.

Pemeriksaan lebih lanjut mengungkapkan adanya dua spesies lalat pengorok daun, yaitu L. huidobrensis dan L. chinensis. Gambar 2 menunjukkan bahwa dari jumlah lalat pengorok daun yang muncul dari kedua varietas bawang daun, jumlah spesies L. huidobrensis jauh berlimpah dibandingkan spesies $L$. chinensis. Pada bawang daun varietas RP, puncak populasi terjadi pada 7 MST. Pada varietas Erwor, puncak populasi terjadi lebih awal yakni pada 5 MST.

Tingkat Kerusakan Tanaman. Tingkat kerusakan tanaman pada bawang daun varietas Erwor selalu lebih tinggi dibandingkan pada varietas RP (gambar tidak disajikan). Lalat pengorok daun tampaknya lebih menyukai varietas Erwor dibandingkan varietas RP. Lebih tingginya tingkat serangan pada varietas Erwor mungkin berhubungan dengan jumlah anakan. Pengamatan jumlah anakan yang dilakukan pada saat menjelang panen memperlihatkan bahwa jumlah anakan pada varietas Erwor lebih banyak dibandingkan pada varietas RP. Tanaman bawang daun yang ditanam satu batang per rumpun menghasilkan 2,44 anakan per rumpun pada varietas $R P$, sedangkan pada varietas Erwor 4,85 anakan per rumpun.
Tingkat Parasitisasi. Analisis ragam pengukuran berulang menunjukkan bahwa varietas bawang daun tidak mempengaruhi tingkat parasitisasi $(\mathrm{F}=0,77 ; \mathrm{db}=$ $1,3 ; \mathrm{P}=0,387)$. Tingkat parasitisasi parasitoid lalat pengorok daun berkisar antara $6,19-66,67 \%$ pada bawang daum varietas RP dan 3,52-48,44\% pada bawang daun varietas Erwor (Gambar 3). Pada bawang daun varietas RP terdapat dua puncak parasitisasi yakni pada 2 MST dan 8 MST dengan nilai sebesar 66,67\% dan $42,86 \%$. Pada bawang daun varietas Erwor puncak parasitisasi terjadi pada 2 MST dan 6 MST dengan nilai parasitisasi $48,44 \%$ dan $41,86 \%$.

Berbeda dengan tingkat parasitisasi, hasil analisis menunjukkan bahwa varietas bawang daun berpengaruh nyata $(\mathrm{F}=13,76 ; \mathrm{db}=1,3 ; \mathrm{P}<0,001)$ terhadap banyaknya parasitoid yang muncul dari daun contoh. Jumlah imago parasitoid yang muncul dari varietas Erwor (13,68 $\pm 10,20$ ekor) lebih banyak dibandingkan dari varietas RP $(6,90 \pm 9,71$ ekor). Banyaknya imago parasitoid yang muncul dari daun contoh berbeda antar waktu. Puncak kemunculan imago parasitoid pada varietas RP terjadi pada saat tanaman berumur 8 MST (111 individu), sedangkan pada varietas Erwor puncak kemunculam imago parasitoid terjadi pada saat tanaman berumur 6 MST (108 individu) (Gambar 4).

Seperti tampak pada Gambar 4 terdapat dua spesies parasitoid yang muncul dari daun contoh, yaitu Hemiptarsenus varicornis dan Opius chromatomyiae. Gambar 4 juga memperlihatkan bahwa parasitoid $H$. varicornis lebih berlimpah dibandingkan O. chromatomyiae. 


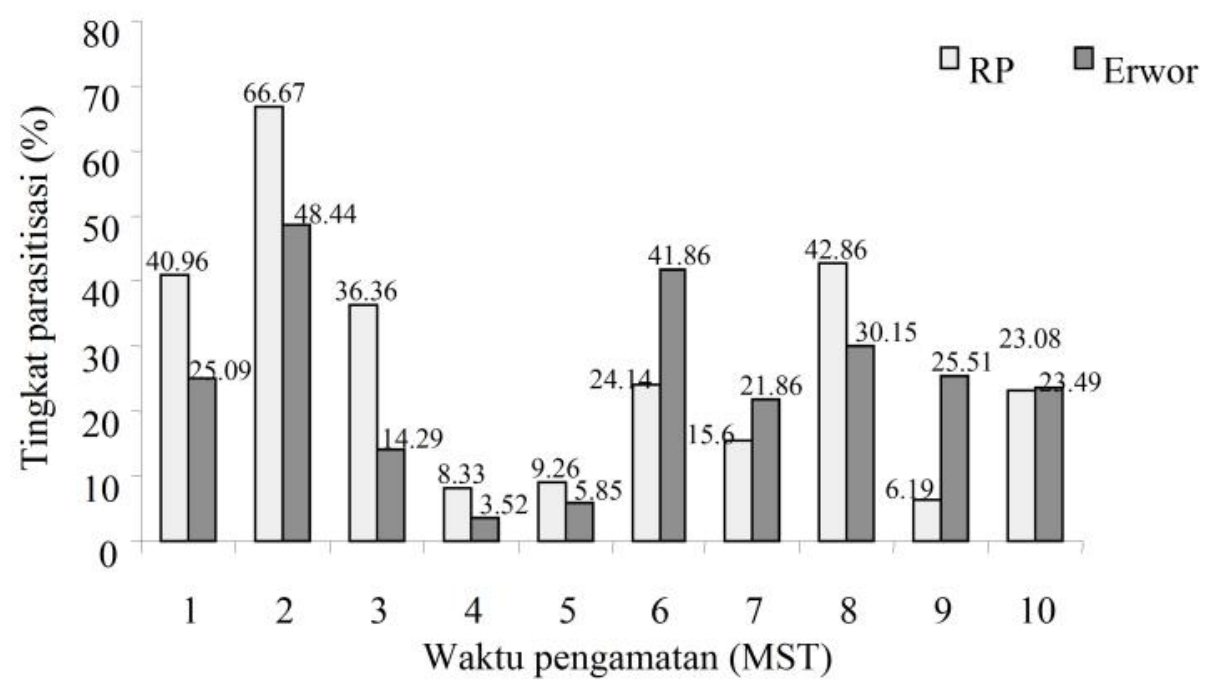

Gambar 3. Rataan tingkat parasitisasi parasitoid pada bawang daun varietas RP dan Erwor
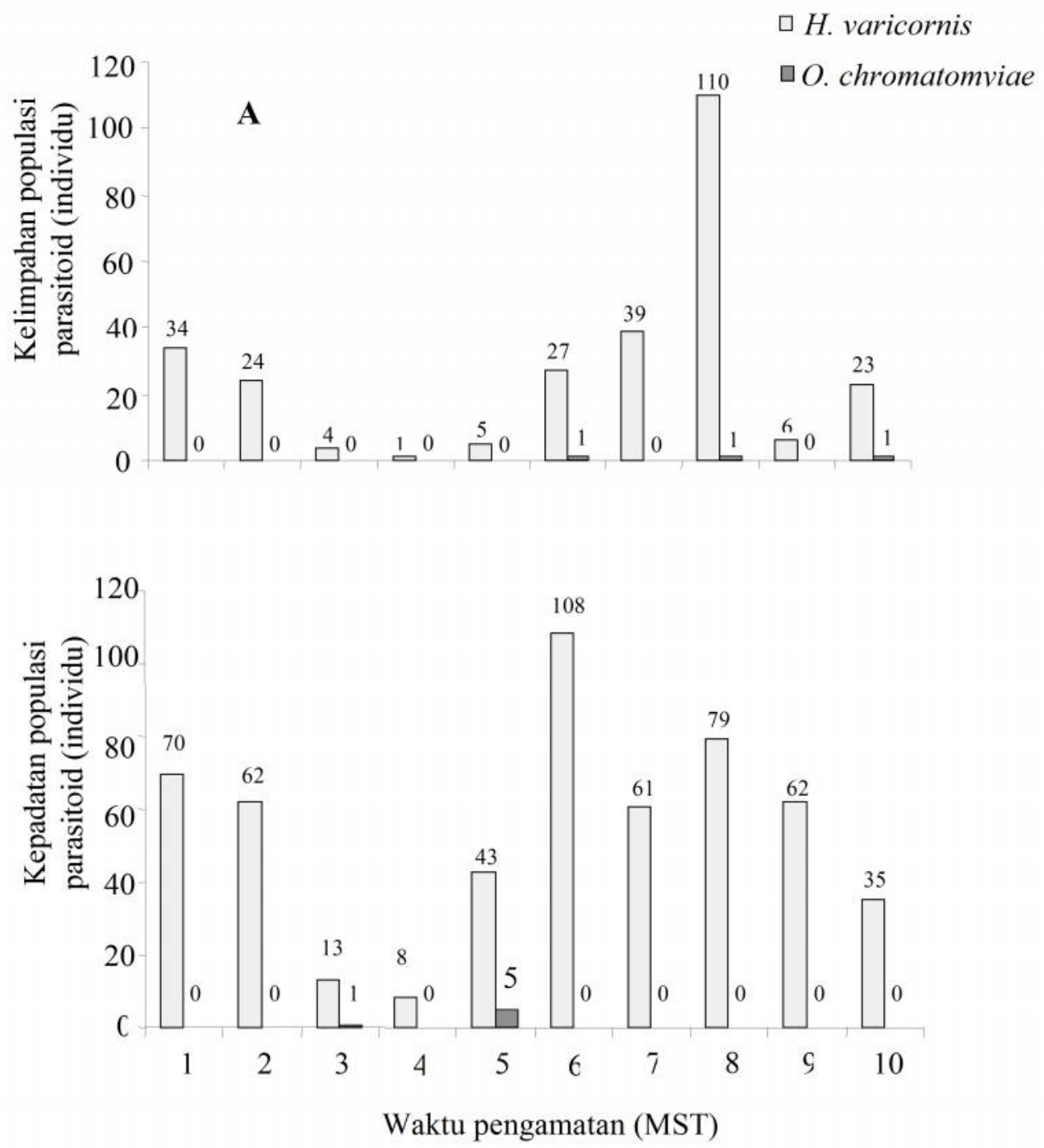

Gambar 4. Kelimpahan populasi Hemiptarsenus varicornis dan Opius chromatomyae pada bawang daun dan varietas RP (A) dan Erwor (B) 
Tabel 1. Parameter hayati imago Opius chromatomyiae

\begin{tabular}{lcccc}
\hline \multicolumn{1}{c}{ Parameter } & N & Minimun & Maksimum & Rerataan \\
\hline Lama hidup imago betina (hari) & 22 & 6 & 14 & $9,95 \pm 2,34$ \\
Lama hidup imago jantan (hari) & 22 & 5 & 20 & $11,73 \pm 4,07$ \\
Laju peneluran (butir/hari) & 22 & 4 & 15 & $9,31 \pm 3,41$ \\
Lama oviposisi (hari) & 22 & 5 & 14 & $9,86 \pm 2,47$ \\
Keperidian & 22 & 68 & 163 & $104,73 \pm 22,09$ \\
Nisbah kelamin keturunan (\%jantan) & 22 & 6,94 & 57,30 & $35,61 \pm 14,04$ \\
\hline
\end{tabular}

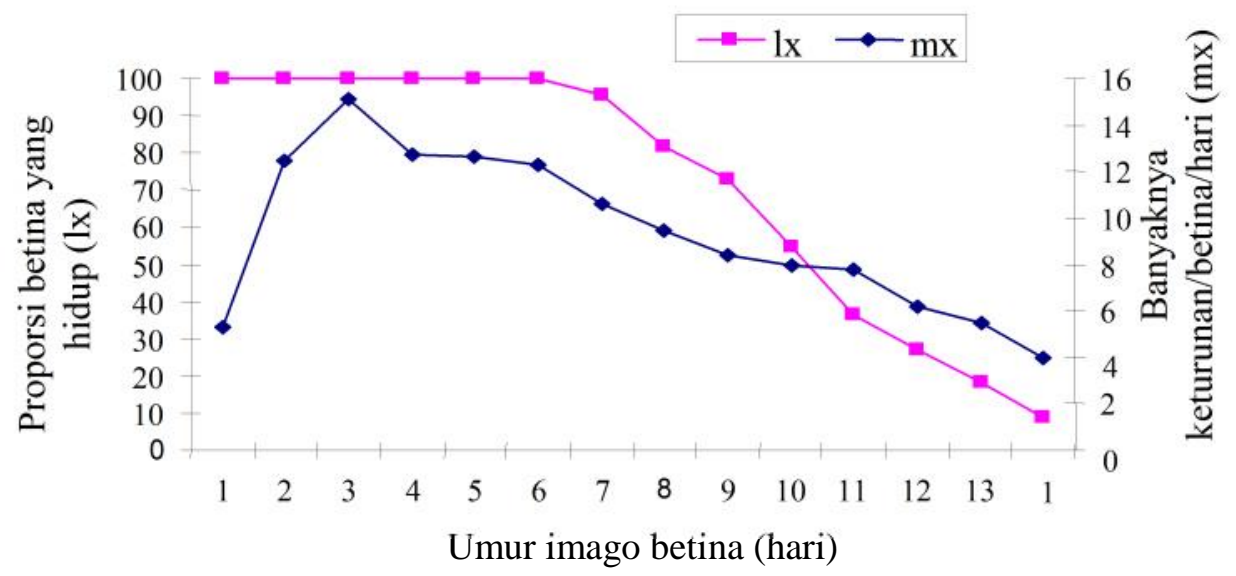

Gambar 5. Kurva sintasan imago betina Opius chromatomyiae

\section{Studi Parasitoid}

Parameter Hayati. Rataan lama hidup imago jantan parasitoid $O$. chromatomyiae sekitar 2 hari lebih lama daripa imago betina. Imago betina yang baru muncul, baik sudah kawin maupun belum, dapat langsung meletakkan telurnya. Periode oviposisi berlangsung maksimum 14 hari dan minimum 5 hari, dengan rataan $9,86 \pm 2,47$ hari. Jumlah keturunan yang dihasilkan oleh seekor imago betina selama hidupnya berkisar 68-163 ekor, dengan rataan 104,73 $\pm 22,09$ ekor. Nisbah kelamin O. chromatomyiae berkisar antara 6,94-57,30\% dengan rataan 35,61 $\pm 14,04 \%$ (Tabel 1).

Peneluran $(\mathrm{mx})$ mulai terjadi pada imago yang berumur 1 hari dan mencapai puncaknya pada imago berumur 3 hari dengan rataan laju keperidian harian 9,31, kemudian terjadi penurunan pada hari berikutnya (Gambar 5). Proporsi individu yang bertahan hidup (lx) menurun tajam sejak imago berumur 6 hari dan mencapai 0 setelah hari ke-14.

Parameter demografi. Laju reproduksi bersih (Ro), laju pertumbuhan intrinsik (r), laju pertumbuhan terbatas (l), waktu satu generasi $(\mathrm{T})$ nilai reproduktif $(\mathrm{Vx} / \mathrm{Vo})$, serta proporsi masing-masing kelas umur pada distribusi umur stabil (px) dihitung berdasarkan data peluang hidup
(Lx) dan keperidian (mx). Hasil perhitungan tersebut disajikan pada Tabel 2.

Parasitoid O. chromatomyiae mempunyai nilai Ro sebesar 28,55. Nilai ini memperlihatkan bahwa ratarata jumlah keturunan betina yang dihasilkan oleh seekor betina induknya adalah 28,55 betina/induk/generasi atau populasi $O$. chromatomyiae berlipat ganda $28,55 \mathrm{kali}$ dalam setiap generasi. Pada kondisi lingkungan tanpa batas, populasi $O$. chromatomyiae dapat berkembang dengan cepat karena memiliki laju reproduksi bersih (Ro) $>1$.

Lama waktu satu generasi (T) O. chromatomyiae adalah 15,96 hari. Nilai ini menunjukkan bahwa dalam waktu 15,96 hari betina O. chromatomyiae yang muncul mampu menghasilkan separuh dari keturunannya. Nilai laju pertumbuhan intrinsik (r) $O$. chromatomyiae adalah 0,21 betina/ induk/hari, dengan laju pertumbuhan terbatas $1=\mathrm{e}^{\mathrm{r}} 1,23$ hari. Nilai ini menunjukkan besarnya kelipatan populasi O. chromatomyiae (ekor) per hari.

Southwood (1995) menekankan bahwa parameter $r$ adalah laju pertambahan per individu atau laju pertambahan intrinsik dimana keperidian dan sintasan maksimal, yaitu pada keadaan tidak ada faktor mortalitas eksternal. Hal ini terjadi bila populasi memiliki jadwal lx 
Tabel 2. Parameter demografi Opius chromatomyiae

\begin{tabular}{lc}
\hline \multicolumn{1}{c}{ Parameter } & Nilai \\
\hline Laju reproduksi bersih $($ Ro $)$ & 28,55 \\
Rataan masa generasi $(\mathrm{T})$ & 15,96 \\
Laju pertambahan intrinsik $(\mathrm{r})$ & 0,21 \\
Laju pertambahan terbatas $(\lambda)$ & 1,23 \\
\hline
\end{tabular}

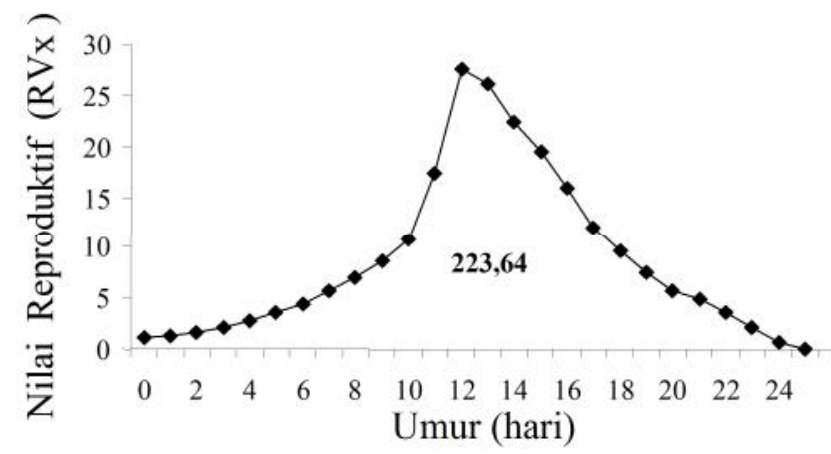

Gambar 6. Nilai reproduksi O. chromatomyiae menurut umur

Tabel 3. Proporsi berbagai fase perkembangan $O$. chromatomyiae pada persebaran umur stabil

\begin{tabular}{cc}
\hline Fase perkembangan & Proporsi (\%) \\
\hline Telur & 37,93 \\
Larva & 24,92 \\
Pupa & 20,36 \\
Imago & 16,78 \\
\hline
\end{tabular}

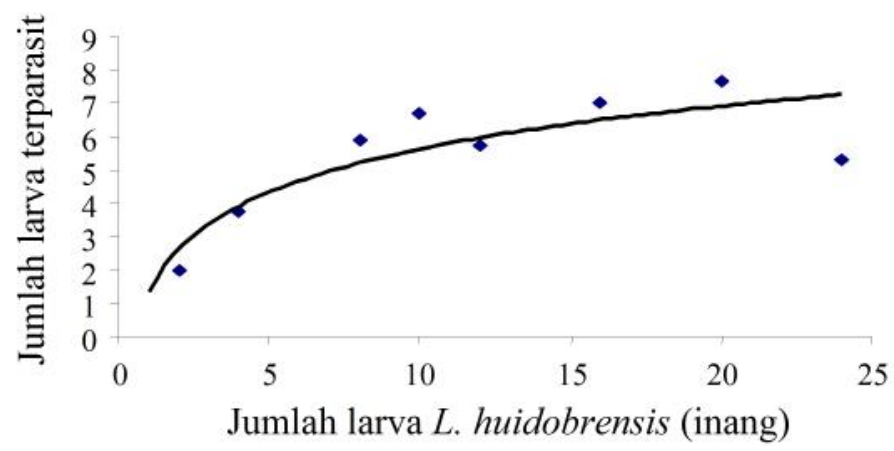

Gambar 7. Kurva tanggap fungsional (Tipe II) Opius chromatomyiae pada berbagai kerapatan larva Liriomyza huidobrensis

dan mx yang tetap serta kematian hanya terjadi oleh faktor fisiologis (Price, 1997). Makin besar nilai r makin tinggi potensi suatu spesies meningkat populasinya pada kondisi lingkungan tertentu. Selain itu, r juga merupakan parameter hayati yang paling penting karena dapat digunakan untuk membandingkan potensi peningkatan di antara berbagai spesies. Dalam hubungan ini, r untuk parasitoid $O$. chromatomyiae $(0,21)$ lebih besar daripada r untuk parasitoid $H$. varicornis $(0,208)$ (Thamrin, 2003). Kedua parasitoid ini memperlihatkan kehidupan yang berbeda. Parasitoid $H$. varicornis bersifat ektoparasitoid sedangkan $O$. chromatomyiae bersifat endoparasitoid, sehingga keduanya dapat saling melengkapi. Seperti halnya $H$. varicornis, parasitoid $O$. chromatomyie juga 
Tabel 4. Hasil analisis regresi logistik proporsi larva Liriomyza huidobrensis yang terparasit oleh Opius chromatomyiae pada berbagai kerapatan inang

\begin{tabular}{lcccc}
\hline \multicolumn{1}{r}{ Parameter } & Nilai penduga & Galat baku & $\chi^{2}$ & $\mathrm{P}$ \\
\hline Titik potong (Po) & 4,1787 & 1,0841 & 14,86 & 0,0001 \\
Linear (P1) & $-0,5360$ & 0,2022 & 7,03 & 0,0080 \\
Kuadratik (P2) & 0,0214 & 0,0116 & 3,41 & 0,0648 \\
Kubik (P3) & $-0,00032$ & 0,000207 & 2,39 & 0,1223 \\
\hline
\end{tabular}

merupakan parasitoid yang potensial karena memiliki laju pertambahan intrinsik ( $\mathrm{r}$ ) yang lebih tinggi daripada r hama L. huidobrensis $(0,17)$ (Supartha, 1998; Purnomo, 2003).

Nilai reproduktif $(\mathrm{Vx} / \mathrm{Vo})$ merupakan ukuran sumbangan relatif individu berumur $\mathrm{x}$ terhadap populasi pada generasi berikutnya. Pada Gambar 6 ditunjukkan bahwa nilai reproduktif pada awalnya terlihat meningkat terus hingga mencapai puncaknya, kemudian menurun dengan bertambahnya umur. Nakamura et al. (1984) menyebutkan bahwa nilai reproduktif suatu individu biasanya meningkat sampai awal masa reproduksi, kemudian akan menurun dengan bertambahnya umur. Nilai reproduktif $O$. chromatomyiae tertinggi dimiliki oleh individu yang berumur 12 hari atau imago berumur 3 hari. Area di bawah kurva memperlihatkan jumlah total nilai reproduktif untuk semua umur, yang nilainya adalah 223,64.

Persebaran umur stabil $O$. chromatomyiae, adalah $37,93 \%$ telur, $24,92 \%$ larva, $20,36 \%$ pupa dan $16,78 \%$ imago (Tabel 3). Kondisi persebaran umur stabil ini merupakan prasyarat bagi tercapainya laju pertambahan instrisik $(\mathrm{r}=0,21)$.

Tanggap Fungsional. Hubungan antara kelimpahan inang dan banyaknya inang yang diparasit disajikan pada Gambar 7. Tampak bahwa makin banyak larva L. huidobrensis yang disediakan makan banyak yang diparasitisasi. Hasil analisis regresi logistik menunjukkan bahwa hubungan antara kelimpahan inang dengan parasitisasi memperlihatkan tanggap fungsional tipe II. Hal ini ditunjukkan oleh koefisien linear yang bernilai negatif (Tabel 4) dan berbeda nyata $(\mathrm{P}<0,05)$. Berdasarkan model tanggap fungsional tersebut, nilai penduga untuk laju pencarian inang a) adalah $0,0777 \pm 0,0354$ per jam, sedangkan masa penanganan inang (Th) adalah 2,5818 $\pm 0,4437 \mathrm{jam}$.
Tanggap fungsional tipe II umum dijumpai pada studi di laboratorium atau dalam kurungan di lapangan yang menyediakan hanya satu jenis inang. Pada kondisi nyata di lapangan, tersedia inang lain bagi parasitoid $O$. chromatomyiae. Adanya pengalihan inang dapat mempengaruhi bentuk tanggap fungsional. Selain itu, habitat inang juga dapat mempengaruhi perilaku parasitoid. Oleh karena itu, agar tanggap fungsional ini dapat digunakan untuk mengevaluasi potensi musuh alami seyogyanya dilakukan percobaan lanjutan dengan mempertimbangkan paling tidak kedua faktor tadi.

\section{SIMPULAN}

Tingkat kerusakan lalat pengorok daun pada bawang daun varietas Erwor lebih tinggi dibandingkan pada varietas RP. Hal ini ditunjukkan pula oleh perbedaan banyaknya lalat pengorok daun yang muncul dari kedua varietas tersebut. Walaupun demikian, banyaknya lalat pengorok daun yang tertangkap perangkap kuning tidak berbeda pada petakan yang ditanami varietas Erwor dan RP. Spesies lalat pengorok daun yang menyerang bawang daun adalah $L$. huidobrensis dan L. chinensis; spesies yang disebut pertama jauh lebih berlimpah. Walaupun tingkat parasitisasi tidak berbeda, banyaknya imago parasitoid yang muncul dari bawang varietas Erwor lebih banyak dibandingkan dari varietas RP.

Parasitoid O. chromatomyiae memiliki potensi untuk dimanfaatkan dalam pengendalian hayati lalat pengorok daun. Hal ini didasarkan pada pertimbangan bahwa $O$. chromatomyiae memiliki laju pertambahan instrinsik yang lebih tinggi daripada inangnya, serta memberikan respons terhadap peningkatan kerapatan inang. Karena $O$. chromatomyiae bersifat sebagai endoparasitoid sedangkan $H$. varicornis sebagai ektoparasitoid, diharapkan parasitoid $O$. chromatomyiae dapat melengkapi peranan parasitoid $H$. varicornis dan sebaliknya. 


\section{SANWACANA}

Penelitian ini merupakan bagian dari Penelitian Hibah Bersaing, Direktorat Jenderal Pendidikan Tinggi, Departemen Pendidikan Nasional Tahun Anggaran 2007. Kami mengucapkan terima kasih atas bantuan hibah yang telah diberikan.

\section{DAFTAR PUSTAKA}

Birch, L.C. 1948. The intrinsic rate of natural increase of an insect population. J. Anim. Ecol. 17: 1526.

Carey, J.R. 1993. Applied demography for biologists with special emphasis on insects. New York: Oxford Univ Press.

CEQ [Council of Enviromental Quality]. 1972. Integrated Pest Management. Washington: US Gov Printing Office.

Holling, C.S. 1959. Some characteristics of simple types of predation and parasitism. The Canadian Entomologist 91: 385-398.

Juliano, S.A. 1993. Non-linear curve-fitting: predation and functional response curves, p. 158-183. In SM Scheiner \& J Gurevitch (editors), Design and Analysis of Ecological Experiments. New York: Chapman \& Hall.

Lysyk, T.J. 2000. Relationship between temperature and life history parameters of muscidifurax raptor (Hymenoptera: Pteromalidae). Environ. Entomol. 29(3): 596-605.

Minkenberg, O.P.J.M. \& J.C. van Lenteren. 1986. The leafminers Liriomyza bryioniae and $L$. trifolii (Diptera: Agromyzidae), their parasitoid and host plants: a review. Agric. Univ. Wageningen Papers 86 (2):1-50.

Nakamura, K. 1984. Survivorship and fertility schedules of two Epilachnine "spesies" feeding on cucurbitaceous plant under laboratory conditions (Coleoptera: Coccinellidae). Appl. Ent.Zool. 19(1):59-66.
Price, P.W. 1997. Insect Ecology. Third Ed. New York: John Wiley \& Sons, Inc.

Purnomo. 2003. Liriomyza huidobrensis (Blanchard) (Diptera; Agromyzidae): Kesesuaian inang, perkembangan populasi, dan pengaruh insektisida translamina [Disertasi]. Bogor: Program Pascasarjana, Institut Pertanian Bogor.

Rauf, A. 1995. Liriomyza: hama pendatang baru di Indonesia. Bul. HPT. 8 (1): 46- 48.

Rauf, A. 1999. Persepsi dan tindakan petani kentang terhadap lalat pengorok daun, Liriomyza huidobrensis (Blanchard) (Diptera: Agromyzidae). Bul. HPT. 11(1): 1-13.

Rauf, A. 2003. Pengembaraan Liriomyza spp. pada awal milenium: respons petani, musuh alami, dan peneliti. Seminar Perhimpunan Entomologi Indonesia, 5-7 Maret 2003.

Rauf, A., B.M.Shepard, \& M.W. Johnson. 2000. Leafminers in vegetables, ornamental plants and weeds in Indonesia: surveys of host crops, species composition and parasitoids. Intern. J. Pest Manage 46 (4): 257 - 266.

Rustam, R. 2002. Biologi Opius sp.(Hymenoptera: Braconidae) parasitoid lalat pengorok daun kentang [Tesis]. Bogor: Program Pascasarjana, Institut Pertanian Bogor.

Rustam, R., A. Rauf, N. Maryana, Pudjianto, \& Dadang. 2008. Lalat pengorok daun dan parasitoidnya pada pertanaman sayuran dataran tinggi di kabupaten Cianjur dan Bogor. Makalah disampaikan pada Seminar Nasional V Perhimpunan Entomologi Indonesia (PEI) Cabang Bogor: Pemberdayaan Keanekaragaman Serangga untuk Peningkatan Kesejahteraan Masayarakat. LIPI Cibinong, Bogor, 18-19 Maret 2008.

Southwood, T.R.F. 1995. Ecological methods 2nd ed. London: Chapman \& Hall. 
Subaidi, A. 2002. Pengujian partikel kaolin dan kapur pertanian untuk penekanan serangan lalat pengorok daun kentang Liriomyza huidobrensis (Blanchard) (Diptera: Agromyzidae) [Tesis]. Bogor: Program Pascasarjana Institut Pertanian Bogor.

Supartha, I.W. 1998. Bionomi lalat pengorok daun, Liriomyza huidobrensis (Blanchard) (Diptera: Agromyzidae), pada pertanaman kentang [Disertasi]. Bogor: Program Pascasarjana, Institut Pertanian Bogor.
Susilawati. 2002. Komposisi dan kelimpahan parasitoid lalat pengorok daun Liriomyza sativae Blanchard (Diptera: Agromyzidae) [Tesis]. Bogor: Program Pascasarjana, Institut Pertanian Bogor.

Thamrin, S. 2003. Potensi Parasitoid Hemiptarsenus varicornis (Girault) (Hymenoptera: Eulophidae): Paralisis, Pemangsaan Inang dan Laju Pertumbuhan Instrinsik [Tesis]. Bogor: Program Pascasarjana, Institut Pertanian Bogor. 